\title{
Insanity legislation
}

\author{
John R Hamilton Medical Director, Broadmoor Hospital
}

\section{Author's abstract}

The McNaughton Rules, which are used when someone pleads insanity at the time of a homicide, are out of date and unsatisfactory. Suggestions have been made about how the insanity defence can be reformulated. The preference of a defence of diminished responsibility means abandoning an ancient and humane principle of not convicting those who are so mentally disordered as not to be responsible for their actions. There is a need for Parliament to consider changes to the law both to prevent the mentally disordered being sent to prison inappropriately, and because the Mental Health Act 1983 has not taken account of rare cases where an offender such as an epileptic might be found legally insane but not mentally disordered.

It is quite perplexing, if not to say vexing to figure what's proper to do, If one of our clan hurts his fellow man, And we feel that he's sure lost a screw.

Thus in recent years like compassionate seers

We have sought to define at the root,

The responsibility of the nonpeaceful dove,

Who insane as a crane, or loose as a goose,

Is compelled or compulsed, confused or revulsed,

By cerebral contusion or inexplicable convolution,

To rape or to maim or to shoot.

It's been sometimes said if a man shoots you dead

And he knew not what's right from what's wrong,

That there should not be criminal responsibility you see,

Due to significant insanity (1).

Criticism of legislation for mentally abnormal offenders these days centres on the Homicide Act 1957 and the concept of diminished responsibility, a state of mind somewhere between full responsibility for one's actions and total lack of responsibility. I believe one should not deal with reformation of the Homicide Act without also considering the Butler Committee's proposals for reforming the McNaughton Rules and

\section{Key words}

Insanity; McNaughton Rules; mentally abnormal offender; homicide; mental illness; forensic psychiatry; epilepsy. disposals under the Criminal Procedure (Insanity) Act 1964.

For many centuries it has been a basic principle in law that no one should be convicted or punished for an offence if he was so mentally disturbed that it would be unreasonable to impute guilt to him. The starting point for legal pronouncements on insanity is often referred to as 'The Wild Beast Test' of 1723:

'It is not every kind of frantic humour, or something unaccountable in a man's behaviour, that points him out to be such a man as is exempted from punishment; it must be a man that is totally deprived of his understanding and memory, and doth not know what he is doing, no more than an infant, than a brute or wild beast; such a one is never the object of punishment' (2).

One had to be almost totally mad to be included in this test and it left no room for those with less than complete forms of mental illness or idiocy. This view was however not always maintained in practice and in 1786 a Margaret Nicholson, who had attempted to kill King George III, was found on arrest to be perfectly lucid but suffering from the delusion that she was the rightful heir to the throne. Kathleen Jones (2) suggests that it may have been the King's knowledge of his own precarious sanity which led him to intervene on her behalf, saying 'The poor creature is mad; do not hurt her; she has not hurt me' and she was sent to Bethlem.

It was a similar attempt on the life of the King in 1800 by James Hadfield which led to the first piece of insanity legislation, the Criminal Lunatics Act of 1800 where the verdict was first brought in of 'not guilty by reason of insanity' and provided for the disposal of the individual by detention in custody during $\mathrm{His}$ Majesty's Pleasure and eventually in an institution for lunatics. Broadmoor was born as a result of the accumulation of large numbers of people found under this verdict between the years 1800 and 1860 when the second Criminal Lunatics Act provided for the building of a national criminal lunatic asylum.

Not long afterwards, the Trial of Lunatics Act of 1883 (prompted by Queen Victoria) led to a change in the verdict to 'guilty but insane' which continued until restored by the Criminal Procedure (Insanity) Act 1964.

In the meantime, in 1843 , the McNaughton Rules 
were set by the House of Lords for judges to apply in insanity trials. They require that to bring in an insanity verdict 'it must be clearly proved that at the time of committing the act the party accused was labouring under such defect of reason from disease of the mind as not to know the nature and quality of the act he was doing, or if he did know it, that he did not know that he was doing wrong'(3).

The McNaughton Rules are generally agreed to be most unsatisfactory and are based on an outdated concept of mental disorder. It has for long been recognised that many mentally abnormal offenders know what they are doing but are undoubtedly severely mentally disordered and this affects their judgement. Cognitive capacity is very often intact whereas delusions may have led individuals to commit homicide but they cannot be found to be insane because they will not fit into the McNaughton Rules. The Rules will not defend someone if he knew what he was doing and if he knew what he was doing was wrong.

Does it all matter given a handful of cases in which the insanity defence is used nowadays? I suggest that it does if we believe in the basic principles of responsibility for mental disorders. The Butler Committee (3) certainly thought the defence should be retained, but revised, and that the disposal of offenders found to be insane should also be changed. Butler considered whether the American 'Durham formula' could be adopted in this country. Under this the accused would not be held to be responsible if his act was 'the product of mental disease or mental defect' but the formula has been criticised because it does not distinguish between minor and major mental disorders. The author of the Durham formula, Judge Bazelon, has himself advocated its abandonment because of the difficulties it has caused. Similarly criticisms have been levelled at the American Law Institute's Model Penal Code which refers to 'a mental disease or defect which results in a lack of substantial capacity to appreciate the criminality of one's conduct or to conform one's conduct to the requirement of law' (3). The main philosophical criticism has been on the concept of ability to conform to what is acceptable behaviour. How can one tell the difference between an impulse which is irresistible and one which is merely not resisted? Kenny (4) describes the notion of irresistible impulse as 'an incoherent piece of nonsense' which cannot be established by science: if psychiatrists called by the defence testify that the accused acted on an irresistible impulse, the prosecution should call a philosopher to testify that there cannot be any such thing as an irresistible impulse.

Butler suggested that the insanity defence should be reformulated so as to allow psychiatrists to state the facts of the defendant's mental condition without being required to pronounce on the extent of his responsibility for the offence. It has often been said (5) that degrees of responsibility are legal, not medical, concepts. The Butler Committee suggested the new wording for the Special Verdict should be 'not guilty on evidence of mental disorder' changing the words from 'by reason of which suggested a causal connection.

The grounds for this new Special Verdict would comprise two elements. The first of these would be a mens rea element similar to the first limb of the McNaughton Rules; did the defendant know what he was doing? The jury would be directed to find this verdict if they thought the defendant did the act, but by reason of the evidence of mental disorder did not find that the state of mind required for the offence had been proved and that it was likely that he was mentally disordered at the time. This first element would apply to any mental disorders other than transient states not related to other forms of mental disorder and arising only as a result of the administration of alcohol, drugs or from physical injury. All other cases currently regarded as non-insane automatism would be within the new Special Verdict. This would widen the scope to include some forms of mental disorder which would currently result in a complete acquittal but this would be balanced by what they proposed as a new discretionary power of disposal - to take into account the individual circumstances. One problem Butler recognised is that psychiatrists would be asked to give an opinion on the accused's state of mind at the time of committing the offence whereas their examination of the individual might take place several months afterwards.

The new second element is intended to provide for $\triangle$ defendants who, although suffering from severe $\overrightarrow{\vec{\sigma}}$ mental disorder at the time of killing, did not come within the compass of the first element because they were able to form intentions and carry them out. The Special Verdict should be returned if the offender was suffering from severe mental illness or severe mental handicap and the Butler Committee proposed a definition of severe mental illness broadly equating with symptoms of psychosis. They suggested that the mental condition should be of such severity that the causative links between the offence and the defendant's mental condition could safely be presumed and the condition should be severe enough of itself to carry freedom from criminal responsibility.

The Butler Committee recommended that the first and second elements of this Special Verdict should be combined in one decision to be made by the jury. Following a return of the verdict the judge should be able to make a disposal appropriate to the individual $o$ case, ranging from the making of a hospital order or $\mathbb{D}$ guardianship order to probation or even an absolute? discharge. At present under the Criminal Procedure (Insanity) Act 1964 the judge has no option but to leave the defendant to be ordered into such hospital as specified by the Home Secretary (and in many cases this $\stackrel{\varnothing}{\varrho}$ is a Special Hospital) where the individual is detained as though made subject to a hospital order together with a restriction order without limit of time. This of course is often the result when a mentally abnormal offender is convicted on the grounds of diminished 
responsibility and is one of the reasons why the insanity defence is so little used. Because the disposal is the same we are forgetting this aforementioned 'ancient and humane principle' of not convicting the severely mentally disordered.

Susanne Dell (6) has recently questioned what practical difference the Butler recommendations will make: the disposal will be the same for most people. The only difference will be that some will be admitted as technically innocent people. She does say that there will be one important and desirable change in the consequences following a technical acquittal in the individual's later life as regards employment, immigration and inheritance. But much more important effects, Dell says, would also flow from the introduction of a usable reformed insanity defence. Under the Butler proposals the courts would not be able to impose a prison sentence on someone found not guilty on evidence of mental disorder. This of course happens at the present time, much to the fury of judges, when hospitals are unwilling to make a bed available, and on other occasions when the offender has recovered during the remand period. Because of the long periods defendants on murder charges spend on remand, and because of the natural history of remission of severe depressive illness, many defendants recover in prison but cannot be sent to hospital because the reporting psychiatrists are unable to say that at the time of their examination the individual is mentally disordered.

The final reason why we must urgently re-examine the insanity laws is because of developments in the law concerning epilepsy and insanity. The case of $R \mathbf{v}$ Sullivan in 1983 followed an assault by Sullivan on an elderly neighbour during an undisputed epileptic automatism. When originally tried at the Central Criminal Court it was ruled that he could plead either not guilty by reason of disease of the mind, in other words insane automatism, or guilty. The plea of noninsane automatism was not available to him. Sullivan's defence took the view that it was preferable for him to plead guilty than to plead insanity with the inevitable disposal. An appeal was dismissed by the Court of Appeal which said that the Special Verdict of not guilty by reason of insanity had to be returned whenever there was evidence of a defendant's total lack of understanding and memory due to a morbid inherent condition of the brain. The case eventually went to the House of Lords (7) where Lord Diplock said that in considering the question of disease of the mind, mind was to be construed in the ordinary sense of the mental faculties of reason, memory and understanding. If the effect of the disease is to impair these faculties so severely as to have either of the consequences of not knowing the nature or quality of one's acts, or not to know that they are wrong, it mattered not whether the aetiology of the impairment is organic as in epilepsy, or functional, or whether the impairment itself is permanent or is transient and intermittent, provided that it subsisted at the time of commission of the act.
Sullivan's case has led to a great deal of discussion and correspondence and to recommendations that Parliament urgently reconsider the question of insanity and this has been accentuated by a more recent case with which I have been personally involved.

This is the case of a 21-year-old man whom I will call Graham and whom I saw for the Crown whilst he was on remand charged with murder. There was no previous psychiatric history though he had been seen by a child psychiatrist as a youngster following shoplifting and other behavioural problems and had received some remedial education. There was however no previous history of violence and although he is not very bright, with an IQ in the dull/average bracket I do not believe one could say he suffered within the meaning of the Mental Health Act from either psychopathic disorder or mental impairment. At the age of 19 he had started to have epileptic fits, and as a result had lost his job as a carpenter and had spent his spare time with other unemployed youths occasionally drinking too much and experimenting with drugs. He had difficulty reconciling himself with the diagnosis of epilepsy and occasionally became depressed and suicidal, cutting his wrists and chest and abdomen and taking a few drug overdoses. His epilepsy had been diagnosed on a clinical basis and he had frequently been observed to have both partial seizures and full grand mal attacks. His electroencephalogram (EEG) has always been normal though approximately 30 per cent of patients with epilepsy have normal EEGs between attacks. He has frequently experienced fits when he feels and sees his body shaking and does not lose full consciousness and he has also experienced auditory, visual and gustatory hallucinations.

The offence occurred in October 1983 on a Sunday, when he felt bored and wished to have an alcoholic drink to rid him of the hangover from his being out at pubs and a party the night before. He did not, however, have any money and he said it occurred to him to steal some money from the gas meter in the house next door. Having attempted to make sure no one was in the house, he entered it but found the gas meter empty and made to leave but was stopped by the lady of the house who confronted him with a poker in her hand. Graham's account of the subseqent events is of a hazy recollection of the lady aiming blows at him with the poker and of him falling on the floor. He says his next memory is of regaining consciousness on the back doorstep of the house and assuming that the lady had knocked him unconscious with the poker. On arriving home his mother said she had heard screaming next door and Graham volunteered to find out what had happened. He re-entered the house to find the lady dead on the floor covered in blood and with his carpenter's chisel beside her. She had suffered three blows including a fatal one to her neck. The police were called, Graham was arrested and after initially lying, admitted that he must have been responsible for the woman's death.

Subsequently on remand he had a number of $\frac{\overline{0}}{\partial}$ 
epileptic fits before his condition was stabilised with anticonvulsant drugs. Following my assessment of him I concluded, in addition to the lack of psychopathic disorder or mental impairment, that he did not suffer from any mental illness but only from epilepsy. In the absence of any witness to the killing I was aware that I was basing my opinion largely on his own account of what happened but was satisfied from the consistency of his account and the background, that on the balance of probabilities he did suffer an epileptic fit during his encounter with his victim, that at that time he was not conscious, his actions were involuntary and that he was not capable of forming an intention to act violently. The opinion I recorded was that his case was one of non-insane automatism and that I could not as a psychiatrist say that the condition he suffered from could properly be called insanity as I did not believe epilepsy was a 'disease of the mind'. In my report however I said I was conversant with the case of Sullivan and the ultimate verdict and opinions expressed in the House of Lords in that case and that 'mind' in law meant the mental faculties of reason, memory and understanding and it therefore followed that at the time of committing the act Graham was labouring under such a defect of reason from disease of the mind that he did not know the nature and quality of the act he was doing and that he came within the McNaughton Rules.

At his trial the matter was fully tested because the prosecution refused to accept the insanity plea, presumably because Graham had initially lied to the police and because there were no witnesses to the killing. Three psychiatrists gave evidence that Graham suffered from epilepsy and many of his fits seemed to be provoked by severe stress. The medical evidence for the prosecution came only from one neurologist who said that it was unlikely that Graham had had a focal seizure during the attack and he was still in some doubt as to whether he did suffer from epilepsy. That matter, however, was put beyond doubt when following most concerted cross-examination by the prosecution Graham suffered a partial seizure in the witness box. The result of the trial was that the jury brought in a unanimous verdict that Graham was not guilty by reason of insanity and in due course under the provisions of the Criminal Procedure (Insanity) Act he was ordered into a hospital specified by the Home Secretary, namely Broadmoor.

All the psychiatrists involved in the case, including myself, recommended his admission to Broadmoor on account of his undisputed dangerousness. Since his admission his epilepsy has been difficult to stabilise and he has on three occasions suffered prolonged status epilepticus. At other times he has, during states of partial consciousness, quite severely attacked those attempting to restrain him.

Much more important though is the question of his detainability. He currently has the legal status of a patient who has been made subject to a hospital order together with a restriction order without limit of time and shares with such patients the ability to apply for a discharge to a Mental Health Review Tribunal within the first six months of admission, again in the second six months and once a year thereafter. Moreover if he does not exercise his right to appeal to a tribunal within the first six months his case must be heard at the end of that period.

At the hearing there will be two important considerations, the first of which is that although the Home Secretary may order the patient into hospital, the Mental Health Act 1983 gives powers to tribunals to discharge restricted patients whether the Home Secretary likes it or not.

Secondly, tribunals have not only discretionary powers but also duties to discharge patients in given circumstances. The first question the tribunal must consider is whether the applicant is suffering from one of the four forms of mental disorder as defined in Section 1 of the Act. These are mental illness, psychopathic disorder, mental impairment and severe mental impairment. It thus becomes possible that a patient who does not have any of these forms of mental disorder (but being epileptic, has been found to be legally insane) will have to be discharged. The tribunal will have the duty to order his absolute or conditional discharge if they do not consider him to have one of these forms of mental disorder. The result would be of course that the patient would walk free immediately whether or not he was considered to be dangerous. No one has apparently foreseen the possibility of someone being found insane but not mentally disordered. It may be that the tribunal will have philosophical discussions on the nature of mental illness which might otherwise be described as illness of the mind which might be thought to be the same as a recurrent disease of the mind, which the lawyers say and the jury has held that this individual has.

I trust Graham's case, albeit a rare one, will be considered carefully when the time comes to reformulate the insanity defence and to consider the Butler Committee's proposals. After Graham's trial I wrote a letter to The Lancet (8) drawing attention to the case and suggesting that Parliament should urgently reconsider the whole question of epilepsy and insanity and pointing out that whereas McNaughton was undoubtedly mad, Graham had been sent to the same hospital as McNaughton though Graham himself is most certainly not mad. I wonder what the public outcry will be when a tribunal is forced to discharge someone who is undoubtedly dangerous. There was considerable public concern in 1843 following McNaughton's trial as demonstrated by this poem from the Weekly Dispatch (9):

Ye people of England: exult and be glad, For ye're now at the will of the merciless mad. Why say ye that but three authorities reign Crown, Common and Lords? You omit the insane! They're a privileged class, whom no statute controls, And their murderous charter exists in their souls, 
Do they wish to spill blood - they have only to play A few pranks - get asylum'd a month and a day, Then heigh! to escape from the mad-doctor's keys and to pistol and stab whomsoever they please.

Fohn R Hamilton MD, FRCPsych, DPM is Medical Director of Broadmoor Hospital, Crowthorne, Berkshire.

\section{References}

(1) Burak C S. The rhyme or reason of criminal responsibility. The journal of psychiatry and law 1978; 6 : $429-432$.
(2) Jones K. Lunacy, law and conscience 1744-1845. London: Routledge and Kegan Paul, 1955.

(3) Home Office and Department of Health and Social Security. Report of the Committee on Mentally Abnormal Offenders. Cmnd. 6244. London: Her Majesty's Stationery Office, 1975.

(4) Kenny A. The psychiatric expert in court. Psychological medicine 1984; 14: 291-302.

(5) Hamilton J R. Diminished responsibility. British journal of psychiatry 1981; 138: 434-436.

(6) Dell S. Wanted: an insanity defence that can be used. Criminal law review 1983; 431-437.

(7) Legal correspondent. Medicolegal: insanity at law. British Medical fournal 1983; 287: 694-695.

(8) Hamilton J R. Epilepsy and insanity. Lancet 1984; ii; 989.

(9) Weekly Dispatch 1843 Mar 12. 